\title{
A PRELIMINARY EXPERIMENT ON THE GROWTH PROMOTING EFFECT OF GROWTH HORMONE WITH THYROID- STIMULATING HORMONE AND PROLACTIN TO THE YOUNG RAINBOW-TROUT (Salmo irideus)
}

\author{
Yoshimasa Enomoto \\ (Received January 6, 1964)
}

\section{Introduction}

In the previous work ${ }^{3)}$, the author reported the extraction of bovine growth hormone after A. E. Wirhelm's method and its growth promoting effect to the young carps. Recentry, G. E. PICKFonD ${ }^{9)}$ suggests the co-operative growth promoting effect of growth hormone with the other anterior pituitary hormones.

Here, the results of a preliminary combination experiment of bovine growth hormone (GH) with thyroid-stimulating hormone (TSH) and prolactin to the young rainbow-trouts are presented.

\section{Material and Methods}

Two hundreds of young rainbow-trouts hatched out in the early spring of 1963 and reared in the Okutama Branch of the Tokyo Fisheries Experimental Station, were transported by car to the Freshwater Fisheries Research Laboratory at Hino on August 1, 1963, precultured with bovine liver for five days, and then were applied to experiment from August 5.

Eight groups, each comprising three rainbow-trouts, were set in the eight glass tanks of $37 \mathrm{~cm} . \times 20 \mathrm{~cm}$. widths and $25 \mathrm{~cm}$. in height, and in each tank, each of three fish was separated with net and reared in the running water of $16^{\circ} \mathrm{C}$. containing about $10 \mathrm{r} / \mathrm{L}$ phosphate and $200 \mathrm{r} / \mathrm{L}$ nitrogen in the rate of 360 litres an hour.

The fish were fed with pellets of which the contents were as follows: crude protein $40 \%$, crude fat $2 \%$, crude cellulose $5 \%$, crude ash $14 \%, \mathrm{Ca} \mathrm{CO}_{3} 0.1 \%$ and the remainder carbohydrates.

Ten grains of this pellet $(0.5 \mathrm{~g}$.) were supplied to each rainbow-trout in the morning and the same in the afternoon. This ration does not show the values eaten by rainbow-trout actually, but does more, as some remained always in the bottom of the tank. The eight different combinations of injections were applied to the eight groups, respectively (Table 1). Injections were made intramusculary between dorsal fin and lateral line to urethane-narcotized rainbow-trout which was fully starved for a day before the injection. Injections were made in every fourth day, being six times

(榎本義正, The Tokai Regional Fisheries Research Laboratory). 
Table 1. Doses of three anterior pituitary hormones, GH, TSH and Prolactin per injection to each of young rainbow-trouts (Salmo irideus).

\begin{tabular}{|c|c|c|c|c|c|}
\hline $\begin{array}{l}\text { Group } \\
\text { number }\end{array}$ & $\begin{array}{l}\text { Number } \\
\text { of fish }\end{array}$ & $\mathrm{GH}^{*}$ & TSH** & Prolactin $* * * *$ & $\begin{array}{l}0.7 \% \text { saline } \\
\text { solution }\end{array}$ \\
\hline 1 & 3 & - & - & - & $0.2 \mathrm{cc}$ \\
\hline 2 & $"$ & $70 r$ & - & - & $"$ \\
\hline 3 & $"$ & $70 r$ & $0.02 \mathrm{IU}$ & - & " \\
\hline 4 & $n$ & $70 r$ & - & $1 \mathrm{IU}$. & $"$ \\
\hline 5 & $"$ & $70 r$ & $0.02 \mathrm{IU}$ & $1 \mathrm{IU}$. & " \\
\hline 6 & $n$ & - & $0.02 \mathrm{IU}$ & - & $"$ \\
\hline 7 & " & - & - & $1 \mathrm{IU}$. & $"$ \\
\hline 8 & $"$ & - & $0.02 \mathrm{IU}$ & $1 \mathrm{IU}$. & $"$ \\
\hline
\end{tabular}

* GH potency: Equi-potent with USP Reference Standard (1 unit/mg.).

** TSH used here has a trade name of Thytropar from Armour Phorm. Co., U.S.A.

*** Prolactin used here is the lactogenic hormone from Teikoku-Zoki Co. Japan.

in total. After 27 days, the fish were killed, weighed and measured in length, and some researches were worked out with blood as remarks.

\section{Results}

All the results are shown in Table 2 .

As to the 1st group to which saline solution was applied, all three individuals were safe and showed $36 \%$ gain in mean body weight. As to the 2nd group, to which saline solution comprising GH was applied, the healthy one showed $108 \%$ gain in body weight while the other two suffered from some exophthalmic disease*. As to the 3rd group, to which saline solution comprising GH and TSH was applied, also two of them suffered from the exophthalmos and the healthy one showed $96 \%$ gain in body weight. As to the 4th group, to which $\mathbf{G H}$ and prolactin was applied, also two suffered from exophthalmos and the healthy one showed $53 \%$ body weight gain. As to the 5th group, to which saline solution comprising $\mathbf{G H}$, TSH and prolactin was applied, one suffered from exophthalmos while the other two showed $46 \%$ gain in mean body weight.

As to the 6th group, to which saline solution comprising TSH was applied, all three were safe and showed $44 \%$ gain in mean body weight. As to 7 th group, to which saline solution comprising prolactin was applied, all three were safe and showed $37 \%$ gain in mean body weight. As to 8th group, to which saline solution comprising TSH and prolactin was applied, all three were safe and showed $36 \%$ gain in mean body weight.

\section{Discussions}

The scarcity of the number of experimental rainbow-trouts, as three in each group,

* Details with this fatal exophthalmic disease are to be presented in the succeeding paper. 
made this experiment of a preliminary one. The scarcity was due to the fact that they had been reared separately in such a space mentioned-above to avoid their quarrels and competitions.

Table 2. The results of the eight rainbow-trout groups for GH, TSH and pralactin injection experiments (reared 27 days from Aug. 12 to Sept. 7, 1963).

Naked numerals in length and weight show the values at the beginning and those in parentheses at the end of the experiments.

\begin{tabular}{|c|c|c|c|c|c|c|}
\hline Group & $\begin{array}{l}\text { Fork } \\
\text { length } \\
(\%)\end{array}$ & $\begin{array}{l}\text { Body } \\
\text { weight } \\
\text { (g.) }\end{array}$ & $\begin{array}{l}\text { Rate of } \\
\text { wt. gain } \\
(\%)\end{array}$ & $\begin{array}{l}\text { Reticulo- } \\
\text { cyte cell } \\
(\%)\end{array}$ & $\begin{array}{c}\text { White blood } \\
\text { cell count }\end{array}$ & Remarks \\
\hline Control & $\begin{array}{l}8.3(9.7) \\
8.4(9.3) \\
8.2(9.3)\end{array}$ & $\begin{array}{l}7.0(10.2) \\
7.6(9.6) \\
6.8(9.2)\end{array}$ & $\begin{array}{l}46 \\
26 \\
35\end{array}$ & $\begin{array}{l}9.3 \\
8.2 \\
8.4\end{array}$ & $\begin{array}{l}34 \\
26 \\
32\end{array}$ & \\
\hline GH & $\begin{array}{l}8.7(-) \\
8.8(11.5) \\
8.5(10.0)\end{array}$ & $\begin{array}{l}7.9(-) \\
8.5(17.7) \\
7.8(12.0)\end{array}$ & $\begin{array}{r}- \\
108 \\
54\end{array}$ & $\begin{array}{r}- \\
9.0 \\
11.1\end{array}$ & $\begin{array}{l}- \\
36 \\
26\end{array}$ & $\begin{array}{l}\text { Exophthalmos } \\
\text { Exophthalmos }\end{array}$ \\
\hline $\begin{array}{l}\text { GH and } \\
\text { TSH }\end{array}$ & $\begin{array}{l}8.4(-) \\
8.5(-) \\
8.7(11.1)\end{array}$ & $\begin{array}{l}6.7(-) \\
7.0(-) \\
7.6(14.9)\end{array}$ & $\frac{-}{-}$ & $\begin{array}{r}- \\
- \\
11.0\end{array}$ & $\frac{-}{24}$ & $\begin{array}{l}\text { Exophthalmos } \\
\text { Exophthalmos }\end{array}$ \\
\hline $\begin{array}{l}\text { GH and } \\
\text { Prolactin }\end{array}$ & $\begin{array}{l}9.1(9.5) \\
8.7(-) \\
9.2(10.3)\end{array}$ & $\begin{array}{l}8.5(9.2) \\
8.0(-) \\
8.9(13.6)\end{array}$ & $\begin{array}{c}8 \\
- \\
53\end{array}$ & $\begin{array}{r}- \\
- \\
15.6\end{array}$ & $\begin{array}{l}- \\
- \\
30\end{array}$ & $\begin{array}{l}\text { Exophthalmos } \\
\text { Exophthalmos }\end{array}$ \\
\hline $\begin{array}{l}\text { GH, TSH } \\
\text { and } \\
\text { Prolactin }\end{array}$ & $\begin{array}{l}8.6(-) \\
8.8(10.1) \\
8.8(9.8)\end{array}$ & $\begin{array}{l}7.2(-) \\
8.6(11.5) \\
7.7(12.1)\end{array}$ & $\begin{array}{l}- \\
34 \\
57\end{array}$ & $\begin{array}{r}- \\
10.1 \\
13.9\end{array}$ & $\begin{array}{l}- \\
58 \\
44\end{array}$ & Exophthalmos \\
\hline TSH & $\begin{array}{l}8.2(9.0) \\
8.6(9.7) \\
8.2(9.3)\end{array}$ & $\begin{array}{l}7.1(10.0) \\
8.3(11.9) \\
7.2(10.7)\end{array}$ & $\begin{array}{l}41 \\
43 \\
49\end{array}$ & $\begin{array}{l}5.6 \\
7.9 \\
4.6\end{array}$ & $\begin{array}{l}26 \\
29 \\
24\end{array}$ & \\
\hline Prolactin & $\begin{array}{l}9.1(9.9) \\
8.4(9.4) \\
9.1(10.2)\end{array}$ & $\begin{array}{l}4.0(11.4) \\
7.2(10.5) \\
9.3(13.0)\end{array}$ & $\begin{array}{l}26 \\
46 \\
40\end{array}$ & $\begin{array}{l}5.4 \\
8.3 \\
5.4\end{array}$ & $\begin{array}{l}28 \\
48 \\
28\end{array}$ & \\
\hline $\begin{array}{l}\text { TSH } \\
\text { and } \\
\text { Prolactin }\end{array}$ & $\begin{array}{l}8.5(8.9) \\
8.3(9.3) \\
9.0(10.2)\end{array}$ & $\begin{array}{l}7.4(8.8) \\
6.7(9.1) \\
9.3(14.3)\end{array}$ & $\begin{array}{l}19 \\
36 \\
54\end{array}$ & $\begin{array}{l}5.8 \\
6.9 \\
4.0\end{array}$ & $\begin{array}{l}28 \\
25 \\
26\end{array}$ & \\
\hline
\end{tabular}

Also, the unexpected death by an exophthalmic disease in four groups to which GH was applied with other hormones, made the analysis of the result more difficult. Yet, some foods for further study might be drawn from this results. In this paper, the results of fishes excluding those, dead or alive, suffered from exophthalmic disease, are discussed. Then, two individuals were conspicuous in body weight gain, the one showed $108 \%$ belonging to the 2nd group injected with GH and the other did $96 \%$ belonging to the 3 rd group injected with $\mathbf{G H}$ and TSH, compared with_36\% mean 
body weight gain in control. The other groups may be said to have not shown any obvious gain, showing $53 \%, 45 \%, 44 \%, 37 \%$ and $36 \%$, respectively, compared to $36 \%$ in control.

The chemical analysis of the total body was worked out with the two of cuntrol and the two which showed obvious body weight gains to know what constituted the body weight gain. As shown in Table 3, the ratios of crude protein to crude ash in GH-injected and GH and TSH-injected ones were much larger as 11 to 12 than those in control of 7 to 7.5. This results coincide with the protein-anabolic agent of $\mathbf{G H}$.

Table 3. The results of chemical analysis of the total body of GH-, GH and TSHinjected rainbow-trouts in comparison with those of control. (Numerals were shown in comparison with ash.)

\begin{tabular}{|c|c|c|c|c|}
\hline Group & Crude ash & Crude fat & Crude protein & Remarks \\
\hline Control $\left\{\begin{array}{l}1 \\
2\end{array}\right.$ & $\begin{array}{l}1 \\
1\end{array}$ & $\begin{array}{l}2.17 \\
2.98\end{array}$ & $\begin{array}{l}6.89 \\
7.53\end{array}$ & $\begin{array}{c}\text { Fixed with } 10 \% \\
\text { formol } \\
\text { " }\end{array}$ \\
\hline GH & 1 & 2.77 & 10.90 & " \\
\hline GH and TSH & 1 & 3.14 & 12.07 & $"$ \\
\hline
\end{tabular}

Though too few in numbers of experimented fish, it might be anticipated that GH independently or with TSH have some growth promoting effect and would be of some meaning to study further in these series in a larger number, in a longer period and in the various hormone doses.

Besides, as to the blood research, the large values of reticulocyte* cell counts in four groups to which GH was injected with or without other hormones coincide with the anaemia in the gill observation and might have some relation with exophthalmic disease which occured also in the same four groups to which GH was applied.

Any conspicuous phenomenon was not observed in white blood cell count and relative number of different white blood cells as shown in Table 3.

\section{Summary}

GH, TSH and prolactin were injected intra-musculary in their various combination to the young rainbow-trouts in summer of 1963, preliminarily. Their body weight gains and some other characters were measured and compared with those of control after rearing for 27 days.

1) Two rainbow-trouts, the one injected with $70 \mathrm{r}$ of $\mathbf{G H}$ in every fourth day and the other done with that and $0.02 \mathrm{I}$. U. of TSH, showed some conspicuous body weight gain as $108 \%$ and $96 \%$, respectively, compared with $36 \%$ in control.

2) These weight gains may be mainly attributed to the gain in protein judged

* Reticulocyte here contains polychromatic erythrocyte and basophilic erythrocyte with the blood stained by WRIGHT's solution. 
from the chemical analysis, as expected from the protein anabolic agent of $\mathbf{G H}$.

3) Some exophthalmic disease occured in the GH- injected groups to which the large values of reticulocyte cell counts were also observed.

The further experiments of these series should be worked out in a larger number, in a larger period and with various hormone doses.

\section{Acknowledgements}

The author wishes to express his cordial gratitude to Dr. T. Kawana (Tokai Reg. Fish. Res. Lab.) and Dr. Y. SAтоm and Messrs. of the Freshwater Fisheries Research Laboratory for their perpetual encouragement to this work, to Mr. CHiBA and Mr. M. Yokоте (Freshwater Fish. Res. Lab.) for their troublesome cooperation in rearing, feeding and blood research, to Dr. S. Sasayama (Tokai Reg. Fish. Res. Lab.) for his kindness during the course of chemical analysis and to Director OKawa of the Okutama Branch of the Tokyo Fisheries Experimental Station for his kind offering of the fry of rainbow-trouts. The author's special thanks are due to Prof. A. E. Wilhelmi (Emory University, U.S. A.) who kindly offered purest GH materials and Dr. G. E. PICKFord (Bingham Oceanographic Laboratory, U.S. A.) who kindly reviewed the results and gave valuable advices.

\section{References}

1) CAtz, B. et al.: Amer. Jrl. Med. Sciences, 237 (1959).

2) DaNowsKI, T.S. et al.: J. Clin. Endocrinol. 15 (1955).

3) ENoмото, Y.: Oral report at General Meeting of Jap. Soc. Scien. Fish., Apr. 1963.

4) GAEBLER, L.: Hypophyseal growth hormone, nature and actions. Mc-Graw Hill, New York

5) Inoue, K. et al.: Clinical biochemistry, Asakura Co., Tokyo (1960).

(1956).

6) Kawamoto, N.: The fish physiology, Ishizaki Co., Tokyo (1956).

7) Kraus, E. J.: Pathologie, 17 (1956).

8) Lashmet, M. H. et al.: Med. Bull. Univ. Michigan, 23 (1957).

9) Pickford, G. E.: Comparative endocrinology, J. Wiley and Sons, New York (1959). 